\title{
EFFICIENT GENE TRANSFER METHOD INTO THE WHOLE HEART THROUGH THE CORONARY ARTERY WITH HEMAGGLUTINATING VIRUS OF JAPAN LIPOSOME
}

\author{
Yoshiki Sawa, MD \\ Keishi Kadoba, MD ${ }^{\text {a }}$ \\ Ken Suzuki, MD \\ Hong-Zhi Bai, MD \\ Yasufumi Kaneda, $\mathrm{MD}^{\mathrm{b}}$ \\ Ryota Shirakura, $\mathrm{MD}^{\mathrm{c}}$ \\ Hikaru Matsuda, $\mathrm{MD}^{\mathrm{a}}$
}

Objective: To confirm gene transfer techniques especially into the whole heart, we tried out a gene transfer method involving liposome with the viral envelope hemagglutinating virus of Japan liposome as an alternative to existing techniques such as cationic lipofection or other viral vectors. Method: For this study, hemagglutinating virus of Japan liposome (H group) or cationic liposome(L group) was used to compare the efficacy of gene transfection of oligonucleotide labeled with fluorescein isothiocyanate and CDNA of $\beta$-galactosidase and human manganese-superoxide dismutase. Fluorescein-labeled oligonucleotide, cDNA of $\beta$-galactosidase, or manganese-superoxide dismutase was complexed with liposomes, DNA-binding nuclear protein, and the viral protein coat of hemagglutinating virus of Japan. After donor rat hearts arrested by cardioplegia had been harvested, the coronary artery during cardioplegic arrest was infused via an aortic cannula with the liposome-gene complex. Next, the hearts were transplanted into the abdomen of recipient rats of the same strain, and all recipients were put to death after 3 days of transfection. Results: Fluorescein isothiocyanate was detected in the nuclei of more than $70 \%$ of the myocytes $(75 \% \pm 14 \%, n=5)$ in the $H$ group compared with fewer than $10 \%$ in the $L$ group $(7 \% \pm 5 \%, n=5)$. The intensity of fluorescein isothiocyanate was significantly higher in the $\mathrm{H}$ group $(979 \pm 112$ FI) than in the $\mathrm{L}$ group $(116 \pm 68 \mathrm{FI}) . \beta$-Galactosidase was expressed in the cytosol of more than $50 \%$ of the myocytes in the $\mathrm{H}$ group $(61 \% \pm 7 \%, n=5)$ compared with none in the $\mathrm{L}$ group $(0 \%, n=5)$. After 3 days of gene transfection, and when exposed to ischemia $\left(30\right.$ minutes, $\left.37^{\circ} \mathrm{C}\right)$ and reperfusion ( 30 minutes, $37^{\circ} \mathrm{C}$ ) with Langendorff apparatus, the hearts transfected with manganese-superoxide dismutase ( $\mathrm{S}$ group, $n=5$ ) showed a significantly higher percentage of recovery of left ventricular end-diastolic pressure ( $S$ vs $C$, $86 \% \pm 3 \%$ vs $54 \% \pm 12 \%)$ and coronary flow $(98 \% \pm 2 \%$ vs $66 \% \pm 12 \%)$ than did the control hearts ( $\mathrm{C}$ group, $n=5$ ). Western blotting analysis showed an apparent increased expression of manganese-superoxide dismutase in the hearts transfected with manganese-superoxide dismutase compared with the control hearts. These results clearly demonstrated that the donor hearts were transfected with fluorescein-labeled oligonucleotide and the $\beta$-galactosidase gene as a result of coronary infusion of the hemagglutinating virus of Japan liposome during cardioplegic arrest at the time of harvest. Furthermore, the hearts transfected with manganese-superoxide dismutase showed significant improvement in tolerance against ischemia-

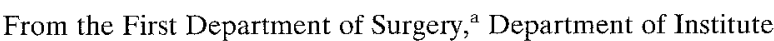
for Molecular and Cellular Biology, ${ }^{b}$ and Department of Organ Transplantation, ${ }^{\mathrm{c}}$ Osaka University Medical School, Suita, Osaka 565, Japan.

Read at the Seventy-sixth Annual Meeting of The American Association for Thoracic Surgery, San Diego, Calif., April 28-May 1, 1996.

Received for publication May 6, 1996; revisions requested June 12, 1996; revisions received Oct. 11, 1996; accepted for publication Oct. 21, 1996.
Address for reprints: Hikaru Matsuda MD, First Department of Surgery, Osaka University Medical School, 2-2 Yamada-oka, Suita, Osaka 565, Japan.

J Thorac Cardiovase Surg 1997;113:512-9

Copyright (C) 1997 by Mosby-Year Book, Inc.

$0022-5223 / 97 \$ 5.00+0 \quad \mathbf{1 2 / 6 / 7 8 7 7 0}$ 


\begin{abstract}
reperfusion injury. Conclusion: We believe that this method represents a novel in vivo gene transfer technique for the heart and thus may provide a new tool for research and therapy of heart transplantation. ( $J$ Thorac Cardiovasc Surg 1997;113:512-9)
\end{abstract}

G ene transfer techniques have recently received Much attention and promise to provide a new approach to the prevention and treatment of a number of acquired disorders, including those in the cardiovascular system. ${ }^{1,2}$ Recently, several groups have demonstrated that plasmid DNA is taken up and expressed in cardiac myocytes after direct injection into the left ventricular wall with or without adenovirus vector. ${ }^{3-6}$ However, this technique still presents several problems such as potential evocation of inflammatory responses, resulting in a deleterious effect on myocardial function and restriction of the transfected area in the myocardium, especially to allow for alterations in the genetic information of the whole heart. ${ }^{1,2}$ Such problems have created the need for alternative techniques that incorporate new approaches as well as several kinds of vectors.

As a means of introducing the vectors specifically into the myocardium, coronary infusion seems to be more efficient than direct injection for gene transfer into the myocardium, provided that the vectors can transmigrate through the endothelium. ${ }^{7,8}$ The best time for coronary infusion of vectors to perform gene transfection to achieve the myocardial protection against the ischemic injury or to change alloreactivity after transplantation (or both) appears to be during the harvesting of the donor heart. ${ }^{8,9}$

We have succeeded in establishing an efficient gene transfer method by using a liposome with viral envelope hemagglutinating virus of Japan (HVJ) liposome. ${ }^{10-13}$ This method is effective even for cardiac myocytes when delivered by coronary infusion when the donor heart is being harvested. ${ }^{13}$

The purpose of this study was twofold: (1) to compare the efficiency of the HVJ liposome method and the lipofection method for gene transfer into the myocardium to confirm the gene transfer techniques into the whole heart with the HVJ liposome method and (2) to evaluate the efficacy of overexpression of human manganese-superoxide dismutase (Mn-SOD) for alteration of genetic information by the transferred gene with this method.

\section{Methods}

Animals. Adult Sprague-Dawley rats weighing 250 to $300 \mathrm{gm}$ were used for this experiment. All rats were anesthetized by intraperitoneal injection of sodium pentobarbital ( $5 \mathrm{mg} / 100 \mathrm{gm}$ body weight).

Oligonucleotide labeled with fluorescein isothiocyanate. In the first experiment, phosphorothioate oligonucleotide labeled with fluorescein isothiocyanate (FITCODN; 16-mer) was introduced into the myocardium with the HVJ liposome method to demonstrate histochemically the localization of the transferred genes. FITC-ODN was kindly provided by Clontech Inc. (Palo Alto, Calif.). ${ }^{13-14}$ ODN was labeled with FITC on the $3^{\prime}$ and $5^{\prime}$ ends of the ODN by using fluorescein-oligonucleotide phosphoramidite.

Construction of plasmid. In the second experiment, the same method was used to introduce cDNA plasmid of $\beta$-galactosidase to demonstrate histochemically the expression of transferred genes. $\beta$-Galactosidase was prepared as described previously. ${ }^{9}$ The Escherichia coli $\beta$-galactosidase gene $(3.1 \mathrm{~kb})$, isolated from pMC1871 by restriction with Sal I, was cloned into pAct-c-myb (a gift from Dr. Ishii, Institute of Physical and Chemical Research).

In the third experiment, we introduced cDNA plasmid of human Mn-SOD with the same method to demonstrate the efficacy of the transferred genes for alteration of cardiac function. A full length of human Mn-SOD cDNA was kindly given by Dr. K. Hirose ${ }^{14}$ and used to construct the Mn-SOD expression vectors designated as pcDNA3Mn-SOD.

Preparation of HVJ liposome. Liposomes containing plasmid DNA and high mobility group 1, which contributes to the enhancement of gene mobility in the cytoplasm to the nuclei, were constituted as previously reported. ${ }^{10-13}$ In brief, dried lipid (phosphatidylserine, phosphatidylcholine, and cholesterol) was mixed with plasmid DNA $(200 \mu \mathrm{g})$ (previously incubated at $20^{\circ} \mathrm{C}$ for 1 hour with high mobility group 1 ) in each group, shaken vigorously, and sonicated to form the liposome. Purified HVJ ( $\mathrm{Z}$ strain) was reactivated by ultraviolet irradiation just before use. The liposome suspension mixed with HVJ was incubated and, after removal of free HVJ, collected for use.

Preparation of cationic liposome. For the L group, cationic liposome, FITC-ODN (30 ng) in the first experiment or cDNA of $\beta$-galactosidase $(200 \mu \mathrm{g})$, was gently mixed with $250 \mu \mathrm{g}$ of the cationic lipid (Lipofectamine [DOSPA: DOPE = 3:1], BRL Life Technologies, Gaithersburg, Md.) in $500 \mu \mathrm{l}$ of sterile saline solution and allowed to form a DNA-cationic lipid complex..$^{15}$

In vivo gene transfection. The rat hearts were transfected as previously reported. In brief, $500 \mu \mathrm{l}$ of HVJ liposome complex or cationic liposome complex was delivered into the coronary arteries of the rat hearts through the aortic cannula during cardioplegic arrest $\left(<15^{\circ} \mathrm{C}\right)$. Then the transfected hearts were heterotopically transplanted according to the method of Ono and Lindsey. ${ }^{16}$ 

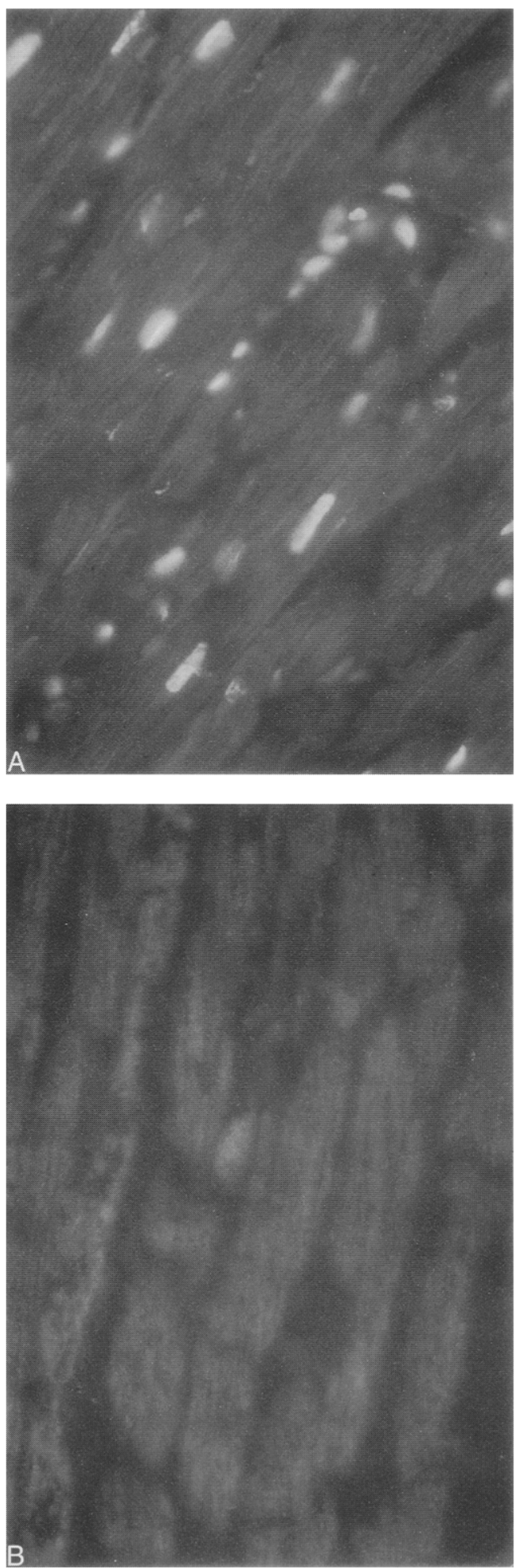

Fig. 1. Localization of FITC-ODN transfection. The $H$ group (A) resulted in an efficient and diffuse transfer of FITC-ODN into nuclei of the myocytes in the myocardium. Transfer was less efficient and diffuse in group L (B).
Mean time of cold ischemia $\left(<15^{\circ} \mathrm{C}\right)$ was $25 \pm 12$ minutes.

Analysis of FITC-ODN. For the analysis of FITCODN, the hearts were isolated, fixed with $3 \%$ paraformaldehyde, frozen at $-80^{\circ} \mathrm{C}$, cut into thin sections, examined with fluorescence microscopy, and micrographed. The same sections were stained with hematoxylin and eosin and photographed with light microscopy. The percentage of FITC-stained nuclei of 200 myocytes was semiquantitatively calculated by comparing the fluorescence and normal micrographs derived from the same area on 10 randomized sections (magnification, $\times 100$ ).

So that the FITC-ODN transferred into the nuclei of myocytes could be quantified, the hearts were homogenized with a digital homogenizer (Iuchi Co., Tokyo, Japan) for 3 minutes to break the sarcolemma and the nuclear envelope of the myocytes and centrifuged $(\times 1500 \mathrm{~g})$ for 10 minutes. The level of FITC at $520 \mathrm{~nm}$ of the supernatant was then measured with a fiuorescence spectrophotometer (RF-1500, Shimadzu Co., Kyoto, Japan) and the intensity was described as fluorescence intensity per gram wet weight of rat ventricle.

Analysis of $\boldsymbol{\beta}$-galactosidase. The hearts were fixed with $2.5 \%$ glutaraldehyde, frozen at $-80^{\circ} \mathrm{C}$, and cut into thin sections stained with 5-bromo-4-chloro-3-indolyl $\beta$-D-galacto-pyranoside (X-Gal) for identification of the expression of $\beta$-galactosidase in the myocardium. ${ }^{13}$ Then these sections were counterstained by hematoxylin and eosin staining. To semiquantify the efficacy of protein synthesis caused by the transferred genes, we evaluated more than 200 myocytes at 10 randomized areas (magnification $\times 100$ ) to calculate the percentage of myocytes expressing $\beta$-galactosidase.

Western blotting analysis of Mn-SOD. Western blotting analysis for detection of overexpressed Mn-SOD was performed in the usual fashion. In brief, total protein was extracted from homogenized myocardial tissue and electrophoretically separated on a polyacrylamide gel. Mn-SOD was detected with monoclonal mouse antibody antihuman Mn-SOD (The Binding Site, Birmingham, England) diluted at 1:10 in a blotting solution. Specific binding was detected with an ECL Western blotting detection set (Amersham Int. plc., Buckinghamshire, UJnited Kingdom).

Evaluation of cardiac function. So that the efficacy of the myocardial protective effect of Mn-SOD gene transfection could be determined in terms of the recovery of cardiac performance, the donor hearts transfected with human Mn-SOD cDNA (S group, $n=5$ ) or empty liposomes (control group, $n=5$ ) were isolated from the recipient abdomen after 3 days of gene transfection. They were then cannulated through the aorta, perfused retrogradely with the modified Krebs-Henseleit solution using the Langendorff perfusion system, and exposed to ischemia (30 minutes, $37^{\circ} \mathrm{C}$ ) and reperfusion (30 minutes, $37^{\circ} \mathrm{C}$ ). After a left ventricular compliant balloon had been inserted through the left atrium, left ventricular developed pressure (at a left ventricular end-diastolic pressure of $10 \mathrm{~mm} \mathrm{Hg}$ ) and coronary effluent flow were measured before and 30 minutes after ischemia. Percentage recoveries of control value of left ventricular end-diastolic pressure and coronary effluent flow were compared between the groups. 
\%FITC staining myocytes

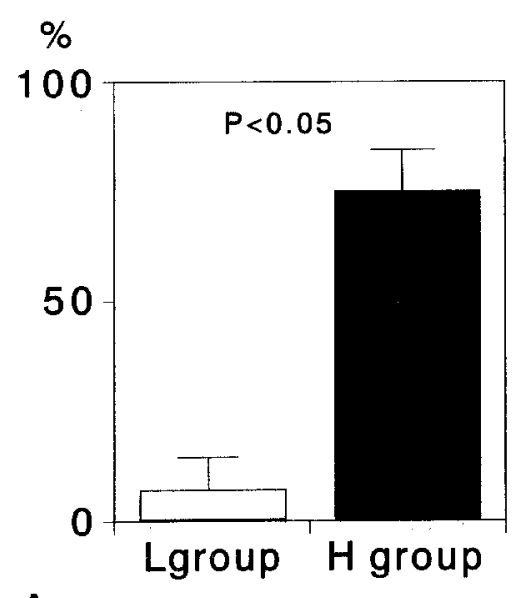

\section{Intensity of FITC}

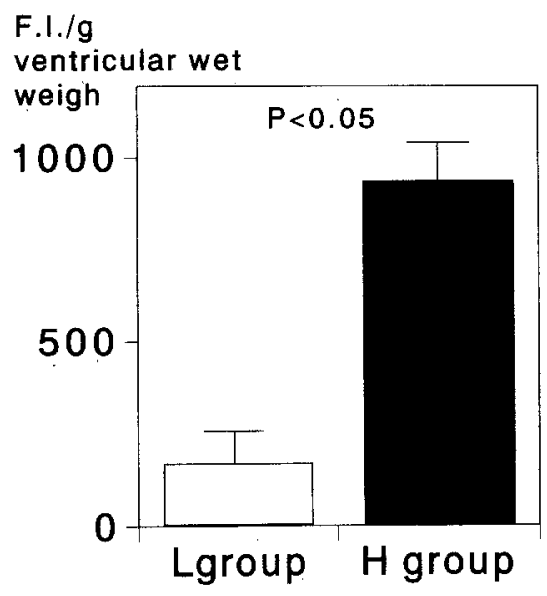

Fig. 2. Efficiency of FITC-ODN transfection. A, Percentage of FITC-stained nuclei of myocytes in the $\mathrm{H}$ group $(75 \% \pm 14 \%)$ was significantly higher than that in the $\mathrm{L}$ group $(7 \% \pm 5 \%)$. B. The $\mathrm{H}$ group (979 \pm $1128 \mathrm{FI} / \mathrm{gm}$ ) showed significantly higher intensity of FITC (FI/gm ventricular wet weight) than did the L group $(116 \pm 68 \mathrm{FI} / \mathrm{gm})$.

Animal care. All animals received humane care in compliance with the "Principles of Laboratory Animal Care" formulated by the National Society for Medical Research and the "Guide for the Care and Use of Laboratory Animals" prepared by the Institute of Laboratory Animal Resources and published by the National Institutes of Health (NIH Publication No. 86-23, revised 1985). We obtained institutional approval of our use of animals and biohazardous materials from the Institutional Review Board of Osaka University Medical School.

Statistics. All values are expressed as mean \pm standard deviation. Student's nonpaired $t$ test was used for a comparison between two groups, and statistical significance was set at $p<0.05$.

\section{Results}

Localization and efficiency of FITC-ODN transfection. In the first experiment, aiming to compare the efficacy and localization of ODN delivery, we introduced FITC-ODN (30 ng/ml) into rat myocardium by coronary infusion with HVJ liposome (group $\mathrm{H}, n=5$ ) or with cationic liposome (group $\mathrm{L}$, $n=5$ ). The $\mathrm{H}$ group (Fig. $1, A$ ) showed a more efficient and diffuse transfer of FITC-ODN into the nuclei of the myocytes in the myocardium than that in group L (Fig. 1, B).

The percentages of FITC-stained nuclei in myocytes were $75 \% \pm 14 \%$ in the $\mathrm{H}$ group and $7 \% \pm$ $5 \%$ in the L group (Fig. 2, $A$ ). The percentage in the $\mathrm{H}$ group was thus significantly higher.
The intensity of FITC (FI per gram ventricular wet weight) was $979 \pm 112 \mathrm{FI} / \mathrm{gm}$ in the $\mathrm{H}$ group and $116 \pm 68 \mathrm{FI} / \mathrm{gm}$ in the $\mathrm{L}$ group (Fig. 2, B). The $\mathrm{H}$ group showed significantly higher intensity of FITC than did the L group.

Efficiency of protein synthesis. In the second experiment, cDNA of $\beta$-galactosidase with HVJ liposome (H group, $n=5$ ) or cationic liposome (L group, $n=5$ ) was introduced into rat hearts to determine the expression of the transferred gene. All hearts in the $\mathrm{H}$ group showed apparent histochemical expression of $\beta$-galactosidase in more than $50 \%(61 . \% \pm 7 \%)$ of the myocytes (Fig. 3, A). However, no such expression of $\beta$-galactosidase was seen in group L (Fig. 3, B).

The efficacy of Mn-SOD. So that the efficacy of Mn-SOD gene transfection could be estimated, the hearts in the $\mathrm{S}$ group and the $\mathrm{C}$ group were sacrificed and prepared for Western blotting at day 3 of transfection. Western blotting analysis showed an apparent increase in the expression of Mn-SOD at $25 \mathrm{kd}$ in the Mn-SOD transfected hearts compared with the control hearts (Fig. 4).

So that the efficacy of the myocardial protective effect of Mn-SOD gene transfection could be determined, the recovery of left ventricular end-diastolic pressure and coronary flow was measured. The percentage of recoveries of control values of left ventricular end-diastolic pressure (S vs C, $86 \% \pm$ 

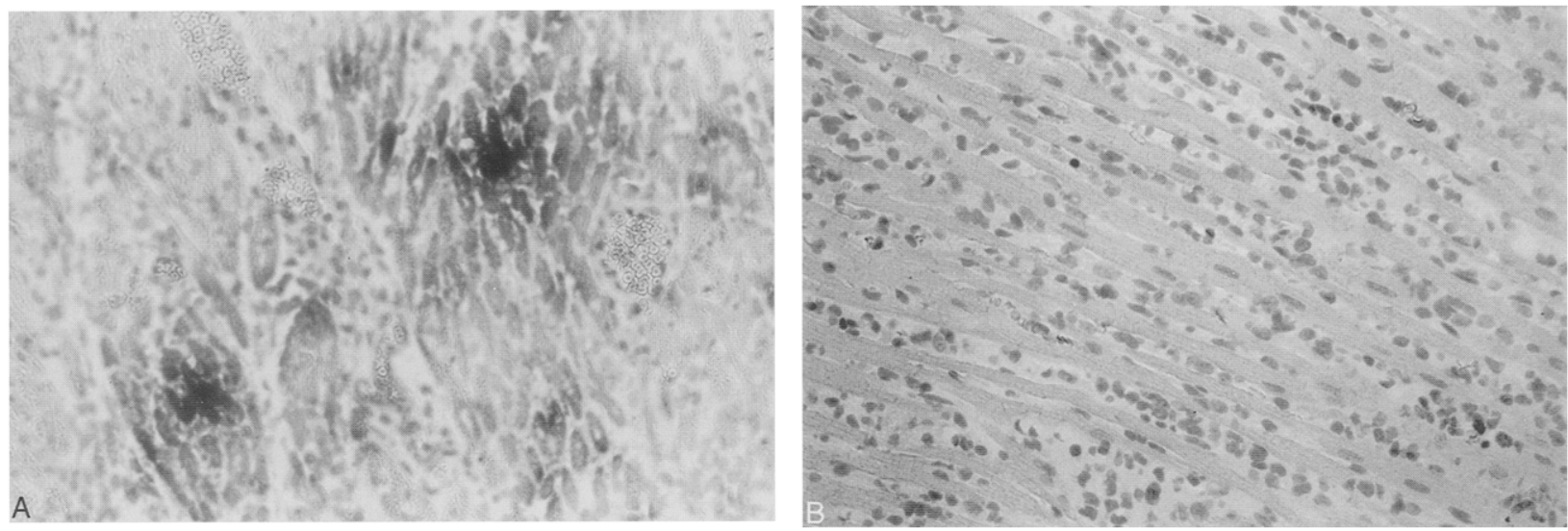

Fig. 3. Efficiency of transfection of $\beta$-galactosidase The hearts in the $\mathrm{H}$ group (A, original magnification $\times 80$ ) showed apparent histochemical expression of $\beta$-galactosidase on the myocytes. However, no such expression of $\beta$-galactosidase was seen in group L ( $\mathbf{B}$, original magnification $\times 80$ ).

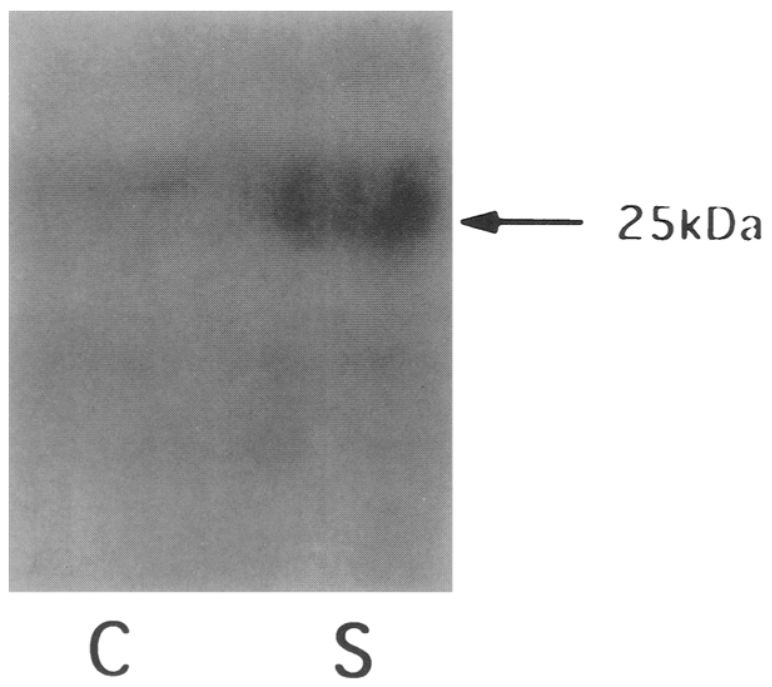

Fig. 4. Western blotting analysis of Mn-SOD. Western blotting analysis showed an apparent increased expression of Mn-SOD at $25 \mathrm{kd}$ in the Mn-SOD transfected hearts as compared with the control hearts.

$4 \%$ vs $51 \% \pm 7 \%$ ) and coronary flow (S vs C, $98 \%$ $\pm 2 \%$ vs $64 \% \pm 12 \%$ ) were significantly higher in the Mn-SOD transfected group than in the control group (Table I, Fig. 5).

\section{Discussion}

The results of this study clearly demonstrated that the hearts were transfected more effectively with both FITC-ODN and CDNA of $\beta$-galactosidase than with the cationic liposome as a result of the gene transfer using the HVJ liposome. Moreover, the hearts transfected with Mn-SOD showed significant improvement of tolerance to ischemia-reperfusion injury. These findings confirm the gene transfer technique into myocardium as a result of coronary infusion of the HVJ liposome during cardioplegic arrest.

In the first experiment, the result of FITC-ODN indicates the localization of the transferred gene. A comparison of FITC intensity between the groups transfected with HVJ liposome and cationic liposome showed that the efficiency of HVJ liposome was about 10 times higher than that of cationic liposome. This result showed that HVJ liposome enhances the gene transfer into the nuclei of myocytes through the coronary artery when HVJ liposome is used as a vector. Moreover, the results of FITC-ODN may hold promise for the use of this method in antisense therapy, an attractive and innovative strategy of gene therapy. ${ }^{17,18}$

In the second experiment, more than $50 \%$ of myocytes in the HVJ liposome group showed expression of $\beta$-galactosidase as compared with none in the cationic liposome group. This result proved the efficiency of protein synthesis after the transfer of the gene into the nuclei with this method. It also suggests that the HVJ liposome method holds a great deal of promise for altering the genetic information in the myocardium.

Although it has been reported that Mn-SOD plays a significant role as an endogenous myocardial protective factor in myocytes, ${ }^{19,20}$ there has been little direct evidence for the efficacy of overexpression of Mn-SOD. Exogenous administration has 
$\% \angle V D P$

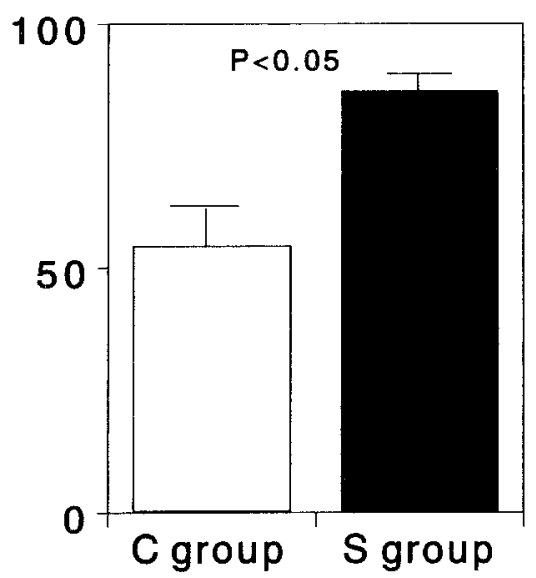

\% Coronary Flow

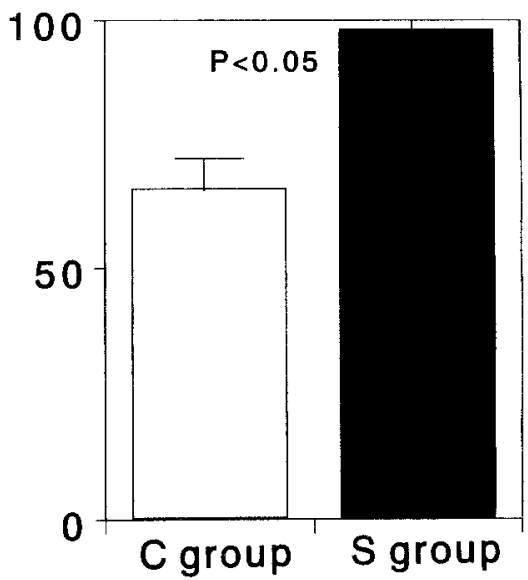

Fig. 5. The efficacy of the gene transfection of Mn-SOD. The percentage recoveries of control value of left ventricular end-diastolic pressure ( $L V D P ; \mathrm{S}$ vs C, $86 \% \pm 3 \%$ vs $54 \% \pm 12 \%)$ and coronary flow $(98 \% \pm$ $2 \%$ vs $66 \% \pm 12 \%$ ) were significantly higher in the Mn-SOD transfected group (S) than in the control group (C).

Table I

\begin{tabular}{|c|c|c|c|c|c|c|}
\hline \multirow[b]{2}{*}{ No. } & \multicolumn{3}{|c|}{$L V D P(\mathrm{~mm} \mathrm{Hg})$} & \multicolumn{3}{|c|}{ Coronary flow ( $\mathrm{ml} / \mathrm{min})$} \\
\hline & Pre & Post & Recovery (\%) & Pre & Post & Recovery (\%) \\
\hline S-1 & 80 & 73 & 91 & 14.1 & 14 & 99 \\
\hline S-2 & 70 & 60 & 85 & 16.5 & 16.2 & 98 \\
\hline S-3 & 99 & 79 & 80 & 12.6 & 12.6 & 100 \\
\hline S-4 & 66 & 55 & 83 & 12 & 11.4 & 95 \\
\hline S-5 & 76 & 67 & 89 & 13.5 & 13.5 & 100 \\
\hline Mean $\pm \mathrm{SD}$ & & & $86 \pm 4^{*}$ & & & $98 \pm 2^{*}$ \\
\hline $\mathrm{C}-1$ & 104 & 58 & 56 & 11.1 & 6 & 54 \\
\hline $\mathrm{C}-2$ & 73 & 31 & 42 & 18 & 13 & 72 \\
\hline C-3 & 93 & 48 & 52 & 20.1 & 9.6 & 48 \\
\hline $\mathrm{C}-4$ & 67 & 29 & 43 & 14 & 10 & 71 \\
\hline C-5 & 61 & 35 & 58 & 11 & 8 & 73 \\
\hline Mean $\pm \mathrm{SD}$ & & & $51 \pm 7$ & & & $64 \pm 12$ \\
\hline
\end{tabular}

LVDP, Left ventricular developed pressure; Pre, preischemic control; Post, 30 minutes after reperfusion.

${ }^{*} p<0.05$ compared with the control group.

limitations in providing such evidence because of the large size of Mn-SOD and the fact that no method exists for introducing these large proteins specifically into mitochondria in the myocytes. However, somatic gene transfer appears to be a potential means to overcome these problems. ${ }^{9}$ In the third experiment, the results demonstrated that rat heart can be sufficiently transfected with Mn-SOD gene by means of this transfection method followed by an improvement in myocardial tolerance to reperfusion injury. This suggests that Mn-SOD acts as an endogenous protective factor in the myocardium. Some mechanisms of this effect have been speculated on in previous reports. One of these is consistent with the scavenging of free radicals leaking from mitochondria. ${ }^{14,19,20}$ Further investigation is needed for clinical use of Mn-SOD gene transfection as candidates for the treatment of myocardial ischemia-reperfusion injury.

For diffuse delivery of genes into the myocardium, the infusion of genes through the coronary artery ${ }^{7,8}$ seems to be superior to direct injection into the myocardium. A recent report indicated the possibility of the infusion of cDNA into the myocardium by 
using a coronary catheter with an inflated balloon while the heart is beating. $7,8,21$ However, this method still limits the transfected area in the myocardium when the whole heart needs to be transfected. This suggests that a specific period of adhesion of vector to endothelial cells is needed for improvement of this technique. These technical considerations may confirm our results that the coronary infusion of HVJ liposome during cardioplegic arrest promises a unique chance to perform in vivo gene transfection into the myocardium.

An opportune time to perform in vivo gene transfection to deliver the vectors may be during harvesting of the donor heart. ${ }^{8,13}$ Although we used a transplantation model that provided good efficiency of gene transfection, our method can be applied to the cardioplegically arrested heart during cardiac operations. ${ }^{13}$ Therefore, these surgical procedures might be beneficial for the clinical application of gene therapy and also offer a unique model for the study of gene therapy.

In summary, the donor hearts were transfected with FITC-OND and $\beta$-galactosidase gene as a result of coronary infusion of HVJ liposome during cardioplegic arrest at the time of harvest. The results were compared with the results of transfection with cationic liposome. Hearts transfected with Mn-SOD showed significant improvement of tolerance to ischemia-reperfusion injury. Our method appears to be a novel in vivo gene transfer technique for the heart to be subjected to ischemia, and thus may provide a new tool for research and therapy of heart transplantation.

We thank Dr. K. Hirose for kindly giving us a full-length of human Mn-SOD cDNA.

\section{REFERENCES}

1. Leinwand LA, Leiden JM. Gene transfer into cardiac myocytes in vivo. Trends Cardiovasc Med 1991;1:271-6.

2. Nabel EG, Pompili VJ, Plautz GE, Nabel GJ. Gene transfer and vascular disease. Cardiovasc Res 1994;28:445-55.

3. Lin H, Parmacek MS, Morle G, Bolling S, Leiden JM. Expression of recombinant genes in myocardium in vivo after direct injection of DNA. Circulation 1990;82:2217-21.

4. Kists R, Buttrick PM, Mcnally EM, Kapkan ML, Leinwand LA. Hormonal modulation of a gene injected into rat heart in vivo. Proc Natl Acad Sci U S A 1991;88:4138-42.

5. Eisler AK, Pedersen EF, Alvira M, Rivera J, Buttrick PM, Wittenberg BA, et al. Quantitative determination of adenovirus-mediated gene delivery to rat cardiac myocytes in vitro and in vivo. Proc Natl Acad Sci U S A 1993;90:11498-502.

6. Guzman RJ, Lemarchand P, Crystal RG, Epstein SE, Finkel $T$. Efficient gene transfer into myocardium by direct injection of adenovirus vectors. Circ Res 1993;73:1202-7.
7. Barr E, Carroll J, Kalynych AM, Tripathy SK, Kozarsky K, Wilson JM, Leiden JM. Efficient catheter-mediated gene transfer into the heart using replication-defective adenovirus. Gene Ther 1994;1:51-8.

8. Ardehali A, Fyfe A, Laks H, Drinkwater DC Jr, Qiao JH, Lusis AJ. Direct gene transfer into donor hearts at the time of harvest. J Thorac Cardiovasc Surg 1995;109:716-20.

9. Quin L, Chavin KD, Ding Y, Woodward JE, Favaro JP, Lin $\mathrm{J}$, et al. Gene transfer for transplantation: prolongation of allograft survival with transforming growth factor- $\beta$ 1. Ann Surg 1994;220:508-19.

10. Kaneda $Y$, Iwai K, Uchida T. Increased expression of DNA cointroduced with nuclear protein in adult rat liver. Science 1989;243:375-8.

11. Kato K, Nakanishi M, Kaneda Y, Uchida T, Okada Y. Expression of hepatitis $B$ virus surface antigen in adult rat liver. J Biol Chem 1991;266:3361-4.

12. Tomita N, Higaki J, Kaneda Y, Yu H. Morishita R, Mikami $\mathrm{H}$, Ogihara T. Hypertensive rats produced by in vivo introduction of the human renin gene. Circ Res 1993;73:898-905.

13. Sawa Y, Suzuki K, Bai HZ, Shirakura R, Morishita R, Kaneda $Y$, Matsuda H. Efficiency of in vivo gene transfection into transplanted rat heart by coronary infusion of HVJ liposome. Circulation 1995;92(Suppl):II497-82.

14. Hirose K, Longo DL, Oppenheim JJ, Matsushima K. Overexpression of mitochondrial manganese superoxide dismutase promotes the survival of tumor cells exposed to interleukin-1, tumor necrosis factor, selected anticancer drugs, and ionizing radiation. FASEB J 1993;7:361-8.

15. Takahashi H, Fujimoto J, Hanada S, Isselbacher KJ. Acute hepatitis in rats expressing human hepatitis B virus transgenes. Proc Natl Acad Sci U S A 1995;92:1470-4.

16. Ono $\mathrm{K}$, Lindsey $\mathrm{E}$. Improved technique of heart transplantation in rats. J Thorac Cardiovasc Surg 1969;57:225-9.

17. Simons M, Edelman ER, Dekeyser JL, Langer R, Rosenberg RD. Antisense c-myb oigonucleotides inhibit intimal arterial smooth muscle cells accumulation in vivo. Nature (London) 1992;359;67-70.

18. Morishita R, Gibbons GH, Ellison KE, Nakajima M, Leyen $\mathrm{H}$, Zhang $\mathrm{L}$, et al. Intimal hyperplasia after vascular injury is inhibited by antisense cdk 2 kinase oligonucleotides. J Clin Invest 1994;93:1458-64.

19. Wisper JR, Warner BB, Clark JC, Dey CR, Neuman J, Glasser SW, et al. Human Mn-superoxide dismutase in pulmonary epithelial cells of transgenic mice confers protection from oxygen injury. J Biol Chem 1992;267:23937-41.

20. Hoshida H, Kuzuya T, Fuji H, Yamashita N, Oe H, Hori M, et al. Sublethal ischemia alters myocardial antioxidant activity in canine heart. Am J Physiol 1993;264:H33-9.

21. Chapman GD, Lim CS, Gammon RS, et al. Gene transfer into coronary arteries of intact animals with a percutaneous balloon catheter. Circ Res 1992;71:27-33.

\section{Discussion}

Dr. Edward D. Verrier (Seattle, Wash.). At the University of Washington, one of our faculty, Margaret Allen, has used a similar method to transfect a number of cells, but she uses just plain liposomes without the viral envelope. And in contrast, she gets about an $80 \%$ transference of the $\beta$-galactosidase reporter gene. How do you think that that makes it more efficient in terms of the transfer? What is the mechanism? 
Dr. Sawa. For in vivo gene transfection into the entire heart, it seems very difficult to transfer gene by plasmid DNA or liposome alone. HVJ has a membrane fusion function. On its lipid bilayer surface, it has two proteins, $\mathrm{HN}$ protein and $\mathrm{F}$ protein. $\mathrm{HN}$ protein can promote adhesion or binding between liposome and endothelial cells, and $\mathrm{F}$ protein acts for fusion after adhesion. Therefore, with HVJ, liposome containing cDNA can easily bind to cells and then such DNA in the liposome can easily go through the cytoplasm and enter directly into the nucleus. The HVJ liposome method appears to work efficiently to promote gene therapy for the heart.

Dr. James K. Kirklin (Birmingham, Ala.). Dr. Sawa, it is my understanding that the duration of expression of these genes is relatively short. Although this method would be potentially useful in ischemic reperfusion models, what about its applicability to the prevention of rejection after transplantation when a longer expression of the gene would be necessary?
Dr. Sawa. With the HVJ liposome method the efficient period of gene transfection is limited. However, an advantage of HVJ is that it can be administered more than two times without any cytotoxicity and antigenicity, unlike adenovirus or other viral vectors. Therefore this method can be applied to prevent rejection for a long time by means of intermittent and repeated administration of HVJ liposome.

Dr. Frank W. Sellke (Boston, Mass.). Did you look at the protein expression for the SOD? There is already a lot of SOD in the vascular tissue and the myocardium, and a small incremental increase may not have a great effect. You clearly showed improvement in function and coronary flow, but did you actually look at the expression of SOD?

Dr. Sawa. In view of the Western blotting analysis, we have already detected the expression of Mn-SOD at $25 \mathrm{kd}$ in the gene transfected heart. Almost all myocytes showed its apparent expression immunohistochemically. 